\title{
Problematizing Familial Relationship: A Study of American Pastoral by Philip Roth
}

\author{
Sarojakanta Nayak \\ Lecturer in English \\ Pattamundai College \\ Kendrapara, Odisha, India \\ mmvexamination2021@gmail.com
}

Abstract

This study is an attempt to show the familial relationship and racial conflicts in Philip Roth's novel, American Pastoral. The study mainly focuses on the treatment of family-relationship and racial conflicts. It intends to find out the way Roth has made an attempt to explore different facets of human relationship through this novel. Being a great artist with exceptional vision, Roth has harped upon some of the most important issues of human relationship. American society and Jewish identity always serve as the main subject matter of his writings. The prime concern of Philip Roth is to bring about reformation in American society in particular and the entire human relationship in general.

Keywords: Family, Identity, Reformation

Philip Roth's novels are mainly concerned with the issues and problems of contemporary upper middle-class life especially through the protagonists or the heroes of the novels. His heroes are sensitive, intelligent and family-oriented. They always care for their family and make all sorts of effort for its betterment. Roth expresses the frustration and disappointments over men-women relationship and socio-cultural oppression in the realm of free view of life. The theme of American Pastoral revolves around a man who has strained all his nerves to safeguard the interest of his family. It also depicts the relationship between 
public and private life in America during the second half of the $20^{\text {th }}$ century. Roth realistically portrays the inner as well as outer experience of a man throughout his novels.

Roth insists not merely on a transformation in the mechanical character of society but also on an overall reformation of the entire social system. Roth's version of the true human relationship can be traced in the reality of love and territories of human experience. He takes up such a mutual regard between the sexes that basically help us understand human reality and help us grow our passional consciousness. He always wants to establish a bond between the sexes. For him love has the potential to transform the entire society and it is capable of producing stability, strength and creative potential in life.

Roth's fictions basically deal with personal tragedy. Through personal tragedy, Roth generalizes the tragedy of the common man or we can say the tragedy of America. From personal tragedy the country is discovered as a whole. Here, we can find the great project of American self-invention and national discovery being presented negatively. In American Pastoral, the tragedy of the Swede is not self-made or self-invented. He wants nothing more than to inherit the role he will play, to act out role that was prepared long before he was born and that will endure long after he is dead. That is one America, but not of Roth's. Roth's argument is that it may be somebody's somewhere; it can never be anyone's America. Therefore, we can say he not only projects his own country but also others' country as well. Philip Roth's present novel American Pastoral has been acclaimed by the common consent as one of the finest creations in the realm of American literature. He has been awarded with Pulitzer in 1998. This novel is the first of his trilogy creation. American Pastoral has concerned with the protagonist named as Swede Levov, a high school star athlete in the world of Newark. He is christened as "Swede" by his basketball coach. He is blond and beautiful. Nathan recollects his life at the grade school where he first met Swede Levov. Seymour was senior to him in the school. Then he describes him as "fair-complexioned, blue-eyed blond 
hero". His gentile like features earned him his nick name-the community placed all of its hopes. While describing Seymour Levov, Nathan Zuckerman says, "The Swede, during the war years, when I was a grade school boy, this was a magical name in our Newark neighborhood. The name was magical, so was the anomalous face of the few faircomplexioned Jewish students in our Jewish public high school, name possessed anything remotely life the steep-jawed, insentient Viking mask of this blue-eyed blond bond into our tribe as Swede." (1998:1)

This novel depicts how a happy and conventional upper middle class life is ruined by the social and political turmoil of the 1960s during the presidency of Lyndon B.Johnson. This novel is described as a manifestation of the "indigenous berserk". Seymour Levov, the main protagonist of the novel journeys from good upper-class life to the lower level of life through suffering. This novel describes the fall of the protagonist from good fortune to bad fortune. Being a simpleton, Swede keeps on dancing to the tune of all his family members. Sacrificing his own ambition, the Swede leaves no stone unturned to live up to the expectation of his family. He tries hard to do justice to all his roles that he is assigned in this novel. The entire novel centres around his character. In other words, his actions or deeds constitute the core theme of the novel. His sincerity and devotion towards his family is beyond any question but he is deprived of having a befitting acknowledgement throughout his life. In the context of the Swede's tragic fall and incomprehensibility of suffering, Roth clearly links Swede to both Oedipus and the Biblical Job. But while Oedipus has an epiphanic moment of reversal and revelation and Job can rely on an all-powerful if incomprehensible God, Swede is left with "the worst lesson that life can teach-that it makes no sense" (81). Merry has shaken the very foundation of his belief system so that Jerry argues her purpose, "That's what she's been blasting away at- that façade. All your fucking norms. Take a good look at what she did to your norms" (1998: 275). 
There are three highly evocative parts such as Paradise Remembered, The Fall and Paradise Lost which deal with the prosperity, tragedy and endurance of misfortune of Swede respectively. This novel is an admission ticket into the American experience of family relationship. In this connection, Stanley in 'Mourning the 'Greatest Generation': Myth and History in Philip Roth's American Pastoral" says, "Encapsulating this struggle in a private family drama, Roth examines the assault against historical metanarratives that constitute the American mythical ideal, interrogating a consensus ideology reflected in a modernist vision of history and literary theory" (2). Roth telescopes American dream and chaos in post modern era in American Pastoral. It also tells the story of a man and the way his life and the regnant social order are shattered by the convulsions of the sixties. American Pastoral is a brilliant expression of battle between the forces of chaos and forces of order.

In Paradise Remembered, Roth, through the voice of Nathan Zuckerman recalls the achievements of Swede as the all-American pride of the Jewish Newark neighborhood. He was the household Apollo of the Weequahic Jews. Roth brilliantly describes the physical appearance of the Swede. According to Nathan, he is the golden boy of the class of 1945-like his country after the war. He is both victorious and virtuous. Because of his heroic quality he has been regarded as the son of God. Everybody likes him and always pays utmost attention to him. At the age of fourteen, he became successful in all spheres of the society. Girls are always ready to develop friendship with Swede. The positive estimation of Semyour Levov is quite conspicuous in the narration of Nathan Zuckerman in the novel.

At the reunion in 1995 Zuckerman meets his old friend as well as classmate Jerry Levov who describes him the tragic derailment of the life of his deceased old brother Seymour "Swede" Levov. In this first section of the novel Zukerman is able to learn of the Swede's family tragedies from the narration of Jerry. Paradise Remembered clearly shows the happy and prosperous life of Seymour in New Jersey. By this conversation with Jerry, 
Nathan was able to know what was mysterious happened in the life of his brother. He tells us the murderous behavior of Merry in order to stop the Vietnam War.

In the section, The Fall the narrator throws light on the tragedies of the main protagonist. He also narrates the situation that results into the life-long suffering of Swede. In the first section, Merry bombed the local post office of Newark. But the result of this bombing is clearly described in the next section. The title of the second part is most appropriate because it vividly throws light on the plight of the "Swede" hou sehold. So, the title "Fall" symbolizes the downfall of the family of Swede. It is more suffering on the part of Swede than the other members of the family.

The last section is known as Paradise Lost. In this chapter, Roth focuses upon the dinner party happened in the last section. This chapter also projects the fall of the house of Levov. It brings to the fore some of the heart-breaking episodes which primarily occur due to the unreasonable action of Merry Levov, the villain of the novel. It also expresses the tender heart of a father towards his children. In addition to this, the last section talks about the extra-marital relationship of Dawn, the wife of Swede. The narrator also reveals that Seymour himself has had an affair with Sheila, Merry's speech therapist. In the context of the Swede's tragic fall and incomprehensibility of suffering, Roth clearly links Swede to both Sophocles Oedipus and the Biblical Job. But while Oedipus has an epiphanic moment of reversal and revelation and Job can rely on an all-powerful if incomprehensible God, Swede is left with "the worst lesson that life can teach-that it makes no sense" (81).

So, from the above interpretation it is quite clear that American Pastoral basically analyzes the relationship between Seymour Levov and his family. It is one of the pioneering achievements in American fiction. It is one of the greatest novels of American upper-class society. This novel creates deep sympathy for "Swede"s household. The household of Swede's family represents the household of every American. From this point of view, 
American Pastoral can be seen as a triumphant culmination of the many 21 th century efforts to give a true and full picture of industrial life. 


\section{Works Cited}

Philip, Roth. American Pastoral. New York: International Publication, 1998, Print.

Stanley, Sandra Kumamoto. “Mourning the 'Greatest Generation': Myth and History in Philip Roth's American Pastoral.” Twentieth Century Literature 51.1 (2005) : 1-24. Print. 